\title{
'Family comes in all forms, blood or not': Disrupting dominant narratives around the patriarchal nuclear family
}

\author{
Daniela Gachago, Lindsay Clowes and Janet Condy
}

\begin{abstract}
After nearly 25 years of democracy lives of young South African's are still profoundly shaped by the legacies of apartheid. This paper considers how these differences are produced, maintained and disrupted through an exploration of changing narratives developed by a small group of South African pre-service teachers, with a particular focus on the narratives developed around discourses of fatherhood generally and absent fathers in particular. We draw on interviews conducted with three students in which we discussed their digital stories and literature reviews. In this paper we draw attention to the limitations of digital storytelling and the risks such autobiographical storytelling presents of perpetuating dominant narratives that maintain and reproduce historical inequalities. At the same time, in highlighting ways in which this risk might be confronted, the paper also aims to show the possibilities in which these dominant narratives may be challenged.
\end{abstract}

\section{Introduction}

It is over twenty years since South Africa's transition to democracy saw the introduction of a constitution outlawing discrimination, alongside the development of legislation aimed at providing the legal foundations upon which to build a more socially just society. And while it should be acknowledged that there has been substantial change, the beginning of the third decade of democratic governance continues to see the lives of South African citizens profoundly shaped by the legacies of the past. Inequalities and differences structured around the apartheid categories of race continue to overlap with class, gender, sexuality and other subject locations to frame and shape interactions, aspirations and opportunities available to South Africans. This paper considers how some of these differences are produced, maintained and disrupted through an exploration of changing narratives developed by a small group of South African students in a diverse pre-service teacher education classroom over the course of one academic year. We draw on interviews conducted with students at the end of 2015 in which we discuss digital stories they produced at the beginning of the year as well as literature reviews towards the end of the year, in which students' evaluated research into one of the themes emerging out of the digital stories. Our focus, in this paper, is on continuities and changes in narratives developed around a specific theme that emerged strongly in both the digital stories and the literature reviews - that of fatherhood generally and absent fathers in particular. We make two key points in the paper. The first is to draw attention to the limitations of digital storytelling and the risks such personal storytelling presents of perpetuating dominant 
narratives that maintain and reproduce historical inequalities. At the same time, in highlighting ways in which this risk might be confronted, the paper also aims to show the possibilities in which these dominant narratives may be challenged.

\section{Digital Storytelling}

Storytelling has been long used as a pedagogical tool that allows diverse learners in the classroom to unearth lived experiences and to facilitate more nuanced understandings of difference (Aveling 2001). Technological change has meant that stories are now easily recordable and shareable through digital storytelling - a method and a genre - that leverages the power of digital media to articulate stories that may not be available via mainstream media (Lambert 2010). As defined in this study a digital story is a personal narrative that documents a culturally and historically embedded lived experience combining voice, sound and images into a short video, developed by non-professionals with nonprofessional tools within the context of a digital storytelling workshop (Lambert 2010; Reed and Hill 2012).

Although originally developed for community engagement, digital storytelling has become widely used as a pedagogical tool in higher education over the last decade. Digital storytelling is seen as offering important opportunities for wide range of learning outcomes, from developing a range of digital literacies (Gumble 2012; Jean and John 2008; Robin 2008), to improving student engagement and reflection (Long 2011; McKillop 2004; Sadik 2008), to developing a professional identity (Condy 2015; Jamissen 2010) or a more confident academic voice (Benmayor 2008; Coventry 2008; Oppermann 2008). As Coventry (2008, 207) observes, the unfamiliar medium of multimodality affords students opportunities to reach a deeper level of learning and reflection: "Working in multimedia brings something to the student's learning that would otherwise not be possible: speaking and explaining through relatively unfamiliar modes of communication helps enforce a deeper engagement with ideas". A similar point is made by Oppermann (2008) who emphasizes the importance, for epistemological access, of a student's personal engagement through digital storytelling with issues discussed in a course (Benmayor 2008; Coventry 2008).

The development and sharing of personal digital stories has also been increasingly used and lauded as a pedagogical tool to engage multicultural classrooms in conversations around difference (Benick 2008; Kobayashi 2012; Sleeter and Tettegan 2002; Walters, Green, Wang, and Walters 2011). Benmayor's work exploring the use of digital stories to 'theorize Latina Life Stories' (Benmayor 2008; Weis, Benmayor, O’Leary, and Eynon 2002) sees students create "transformational stories, that engage histories of resistance, struggle, and survival, and affirm new consciousness in the making” (Weis et al. 2002, 158-159). Students are inspired, she argues, by critical readings by Latina women to theorize their own stories against these readings: “... personal experience becomes theorized, situated". She argues that the multimedia process enhances students' understanding of what it means to theorize their own identities 'from the flesh' by combining experiential, emotional learning with an intellectual analysis based on the reading of critical texts. She concludes that not only do marginalised students gain from the process, but privileged students also experienced transformation, allowing them to understand their realities in more meaningful ways: “... the collaborative practices in 
digital storytelling deepen understanding across social categories of identity and difference in ways that I have not experienced in any other course over my more than 30 years of teaching" (ibid 2002). In a similar fashion, white teacher candidates deconstruct 'Whiteness' in Matias and Grosland's (2016) study, by reflecting on their own identity in a digital story framed by critical literature on critical race theory and critical whiteness studies.

In general then, digital storytelling is lauded in the literature for its potential to facilitate an understanding across difference, allowing empathy and compassion for the 'Other'. For South African educators digital storytelling offers rich pedagogical possibilities for creating space for students to highlight issues and experiences that matter to them (Thumbran 2010) and that may otherwise be subordinated by the gendered, raced, sexualized, classed (and other) hierarchies that continue to privilege certain groups and that underpin the dominant discourses maintaining the status quo (Choules 2007; Maher and Thompson-Teteault 2001; Nash 2013; Weber 2010).

At the same time several critical voices have emerged. Gachago (2015) or Poletti (2011) argue that an uncritical approach to the production of digital stories or to the digital storytelling genre per se, runs the risk, of perpetuating the same dominant narratives that need to be challenged.

This is true for all autobiographical storytelling. Haug $(1992,17)$ for example warns that sharing individual stories does not automatically lead to greater understandings. Likewise hooks $(2000,26)$ observes that while "... the ability to see and describe one's own reality is a significant step ... it is only a beginning". In calling for an examination of the "... the personal that is political, the politics of society as a whole, and global revolutionary politics" hooks $(2000,27)$ thus draws attention to the importance of a critical analysis of personal experience against the local and global discourses that underpin inequality (Apple 2001, see also Alvanoudi 2009; Connell 2014; Nash 2013; Weber 2010). Haug (1992) notes that moving beyond a "... simple duplication of the everyday with all its prejudices and lack of theoretical insight" towards social actions requires us to “... uncover the social construction, the mechanisms, the interconnections and significance of our actions and feelings".

More recently, Poletti (2011, p. 73) questions the potential of digital storytelling with its emphasis on closure, affect and universality "to articulate the relationships between personal experiences of structural social and political inequalities". What follows, is that in an unequal society such as South Africa, where racial, ethnic, patriarchal and other differences and inequalities have been naturalised, their reproduction in digital stories may inadvertently serve to reinscribe the status quo. This paper is a direct response to these shortcomings - identified in previous studies (Gachago et al. 2015; Gachago et al. 2013; Gachago 2015) - by reflecting on an attempt to expand the digital storytelling process with a literature review, drawing from the work of academics such as as Benmayor (2008) and Oppermann (2008), who have modified the digital storytelling process by framing the digital storytelling process with critical readings or combining digital storytelling with reflective essays, in order to facilitate more critical engagements with dominant narratives. 


\section{Context and Methodology}

It is against this theorising and in response to a South African National Department of Education policy initiative aimed at preparing future teachers for diverse classrooms (National Department of Education 2001; Desai, Giliomee, Jordan, Krog, Kulati, Leholo, Leibowitz and James 2004) that a digital storytelling project involving final-year preservice teacher education students in a Faculty of Education at a University in the Western Cape, South Africa, was set up in 2010. Reflecting national and regional demographics, the majority of students in the class come from working class backgrounds and would have been classified by the apartheid regime as Coloured and African ${ }^{1}$. It was hoped that digital storytelling employing new media technology and innovative practices would offer opportunities for students to develop heightened understandings of their own and their peers' social positioning thus enabling them to engage more critically with differences and inequalities structured around race, class, gender, sexuality and other relevant social positionings (Condy 2015; Gachago, Cronje, Ivala, Condy and Chigona 2014; Gachago, Ivala, Condy and Chigona 2013). Initially located at the end of the course, it became clear there was little or no time for students to reflect more carefully on overlaps, commonalities or contradictions emerging out of the digital stories. In the absence of critical reflection the likelihood that students acquire a superficial understanding of difference risks reinscribing existing hierarchies is high (Gachago 2015; Gachago, Ivala, Chigona and Condy 2015; Gachago et al 2014, Stewart and Gachago 2016; Zembylas 2013).

As a result 2015 saw the digital story making component shifted to the beginning of the course and a research project developed to evaluate this shift. Involving students in research that explores one's own teaching presents important ethical challenges and amplifying this was that student's stories are highly personal. Mindful of students' vulnerabilities, we subscribe to the guidelines for an ethical practice for digital storytelling developed by Amy Hill for the StoryCenter ${ }^{2}$, and also obtained ethical approval by meeting the highest guidelines developed by the institution. Students were invited to participate only after the aims of the study had been explained and any questions about the study addressed. Participation was contingent upon their signing a consent form in which they declared that they understood that their participation was voluntary, confidential and anonymous and they also had the right to freely withdraw at any time. All names and identifying features have been changed accordingly.

In 2015, then, students began the academic year in February with a 6-week project in which they developed their digital story. By the end of March 77 digital stories had been written, produced and then screened publically. Towards the end of the year students

\footnotetext{
${ }^{1}$ While we reject these racialised and racist categories, they remain salient in dominant discourses in terms of imperatives around redress, are implicated in experiences on campus and are clearly in common and normative use by students and their families. We use these categories in order to contextualize the narrators within South African historical and contemporary contexts. In this context Coloured refers to a specific racial category, relating to people of Malaysian, mixed-race, and from Khoisan ancestry.

${ }^{2}$ See http://static1.squarespace.com/static/55368c08e4b0d419e1c011f7/t/579134a05016e13dde264720/14691339846 11/Ethics.pdf
} 
were required to produce a literature review, exploring one of the overlapping themes emerging out of the digital stories they had shared, as well as from their teaching practice experiences. Students formed groups based on research topics to share literature and were encouraged to read and comment on each other's drafts. However, the final literature reviews were not shared among students due to time constraints linked to the ending of the academic year. The course convenor, who marked these essays provided individual feedback to students.

Of the digital stories more than half - 40 altogether - had spoken about students' relationships with their fathers. While some - eleven - spoke about fathers who were present, but abusive to their children and/or the mothers of those children, a substantial majority (28) focused on absent or missing fathers. The absence of fathers had a variety of causes: two stories dealt with the deaths of beloved fathers, others revealed that fathers were 'missing' as a result of work commitments or as a result of substance abuse or because they had left to start polygamous families. Overall students were in broad agreement that this absence was a personal problem that had been harmful to their individual development. Twenty one of the literature reviews also focused on the phenomena of missing or absent fathers and, as we show below, while many of these continued to reinscribe the dominant narrative, there were signs that some students had developed more critical understandings.

Feminist research methodologies are concerned with unpacking, reflecting on and disrupting power differentials and decentring male, White, Western hegemonic discourses and knowledges. In considering the continuities and disruptions in the narratives produced by students we thus employed a feminist qualitative thematic analysis informed by critical discourse analysis (drawing on the work of authors Burman and Parker 1993, Parker 1992, Potter and Wetherell 1987 and van Dijk 1993). We begin by describing the dominant discourses around fatherhood emerging in the digital stories at the beginning of the year. We then move on to discuss, in more detail, the ideas of three students. At the beginning of the year all three had produced digital stories about their parents: Liesl about growing up in a strong female-headed family, Sheree about her regret of never having re-established her relationship with her father after he 'abandoned' her mother and herself to marry another woman and start a second family and Magmoed about growing up in a traditional Muslim family and feeling emotionally abandoned by his parents. All three chose to focus their literature review on the issue of missing fathers but demonstrated a more critical understanding of the dominant narratives produced in the digital stories than their peers. In considering their ideas, as articulated in their literature reviews against the background of dominant understandings of absent fathers emerging out of the digital stories, we also draw on interviews conducted with the students at the end of the course and early in 2016.

Reflecting on our own positionality is critical in the context of this paper. Authors 1 and 3 have been working for many years on the digital storytelling project. Author 1 is an educational technologist and author 3 a teacher educator. We are acutely aware that our reading of the data is shaped by our histories and experiences as older, white middle class women just as our students' experiences and understandings are shaped by their positionalities. While we have engaged deeply with the topic of digital storytelling in 
teacher education for social justice, we are not experts in the field of masculinity studies and most likely just as steeped in dominant discourses around masculinity as our students. In order to critique some of the dominant discourses in our students' work we approached a feminist colleague from gender studies (author 2), who provided this expertise.

\section{Dominant discourses: families, fathers and fatherhood}

The kinds of narratives of gender emerging out of the digital stories at the beginning of the year need to be understood against dominant narratives of gender globally. Fatherhood, and the experiences, practices, and understandings of what it means to be or to have a father in different contexts has become an important focus of gender research globally (Lupton and Barclay 1997; Marsiglio 1993) as well as locally (Clowes, Ratele and Shefer 2013; Langa 2010, Ratele, Clowes and Shefer 2012; Richter and Morrell 2006; Swartz and Bhana 2009). In South Africa research exploring questions of fatherhood has drawn attention to the fact that a large - and increasing - proportion of South African children grow up in homes without fathers, with the proportion of children whose fathers were alive but who did not live with their children increasing from $42 \%$ in 1996 to $48 \%$ in 2009 (Holborn and Eddy 2011, 2). While there are marked differences across race and class positionalities, Holborn and Eddy suggest that the 'typical' South African child is raised in a single parent household by her or his mother (Holborn and Eddy 2011, 1).

On the one hand then, the phenomenon of missing fathers can be understood as a significant one, one that is worthy of research. On the other the very idea of 'missing' fathers emerges out of particular understandings of family and the privileging of the 'nuclear' family comprising biological mother, father and children. It is, moreover, the absence of the patriarchal biological father in the nuclear family that is presented as problematic (Clowes, Ratele and Shefer 2013). A fairly recent development in human history, even in the urban industrialised world (Brown and Barker 2004; Burgess and Russell 2004), the 'nuclear' family has never been normative in South Africa (Crehan 1997, Geffray 1990, Oyewumi 1997 cited in Arnfred 2001; Bozalek 2004, 2007). As Brown and Barker note 'the roles of uncles, grandfathers, stepfathers and the extended kin network of the majority world has not been examined nearly as much as the nuclear family of the minority world' $(2004,29)$.

One consequence of the privileging of the nuclear family in research, policy and social interventions in South Africa has been the development of a dominant discourse foregrounding the emotional, relational, educational and material problems associated with a father's absence from the supposedly normative nuclear family (Swartz and Bhana 2009). In South Africa, as elsewhere, this dominant understanding underpins beliefs that children 'without fathers' suffer emotional, psychological and material harm (Holborn and Eddy 2011), with absent or 'deadbeat' fathers understood to present a serious obstacle in the way of developing a more socially just and democratic South Africa (Madhavan, Richter, Norris and Hosegood 2014, 452). 


\section{Findings}

\section{The (digital) story of missing fathers}

That fatherhood in general - and physically and/or emotionally absent fathers in particular - should be such a dominant theme emerging from the stories told by these students has to be understood against a context, briefly outlined above, in which dominant discourses position the nuclear family as normative. It is thus not necessarily surprising that so many of the digital stories and literature reviews narrated experiences of missing fathers. One of the strongest, most striking themes in the digital stories last year, and echoed in local literature, was students' longing for the idealised dual parent family (Clowes, Ratele and Shefer 2013; Ratele, Shefer, and Clowes 2012; Swartz and Bhana 2009), as depicted by the following two quotes. The first quote shows the desire, experienced as physical 'hunger' by the student for a father-daughter relationship, while the second quote shows the normative expectation of a dual/nuclear family.

As much as my hunger for a father and daughter relationship became more intense, I realized that I could not block out reality, my father had no intention of ever trying to build that relationship.

Like any child out there I think I deserved a family, being raised by a single parent wasn't sweeter at all, a single parent who did have a lot to give but to put food on the table.

In digital stories about physically absent fathers students consistently painted pictures of 'broken' selves, families, communities and societies. 'Do you want to see me broken?' one student asked of his missing father in his digital story, 'Do you want to see your own child become a failure in life? Do you want to see me as a victim of alcohol? Talk to me!' Underpinning these stories about missing fathers were personal anxieties about individual futures:

I have been walking in the darkness in life, seeking for my father's guidance, looking for a man who is going to teach me man qualities but he was nowhere to be found. I tried to bring some lights wishing that you might appear somewhere but I couldn't find you.

What kind of a father will I be ... That's the question I keep on asking myself? What kind of a father will I be?

The actual case was that I became more angry and aggressive when things didn't play out according to my expectations. Ironically enough I became more and more the man I dreaded to become ... My father! If I continue being this man, am I going to be okay settling to be like him?

Other students foregrounded the negative consequences of emotionally absent fathers, how coming from what they labelled as 'unstable' homes, had lead them to engage in a variety of destructive behaviours including violence, substance abuse and problems at school:

The history of violence has a big effect on my life and eventually I turn out to be a violent person myself. I become a bully by preying on weaker children at school. Drink becomes my master and hope is taken away from under my feet. 
This picture reminds me of the years I rebelled and looked for comfort in alcohol, tik, dagga 3 and relationships. I felt like a product whose expiry was long overdue. I felt that I was no longer wanted or needed.

Then I started searching, maybe my happiness lies somewhere else. I started doing things that I thought would ease the pain, sadly enough that wasn't the case.

The digital stories produced by the three students whose literature reviews we consider later foreground similar anxieties about missing fathers, be it a physically or an emotionally missing one. All three students are in their mid-twenties and all are coloured. Presented as a letter to her father, Sheree's story articulates the pain and loss she experienced when, under Islam he took a second wife and began a new family, ending, eventually in her mother divorcing her father. In the letter that is the narrative vehicle for her digital story she expresses her regret that, since his death, there is no possibility of reconciling.

I still talk to you daddy, do you hear me? I can still remember your voice, and I always dream of you. I am getting married soon, I have grown up daddy. I do forgive you, I just wish I could forgive myself.

Magmoed grew up in a farming community in the Western Cape. His story entitled 'The orphan' is also written as a letter addressed to his parents, even though his father was present. It contains a list of complaints about how he felt 'robbed' of his childhood, abused and neglected as an 'orphan' because the work he was required to do in the family business disrupted what he imagined his childhood should have been. His story is not about a physically missing father, but about the emotional abandonment he felt by his father, and his father's failure to live up to normative expectations of the patriarchal provider in the nuclear family.

Father ... why did you steal my 1374 hours when I did not have a choice but to work for you? I want that back please. Where is all the please, thank you, well done, you've done your best, keep doing so well, I am proud of you? I want that please. Why did you never ask me if I needed anything and mean it, I want that back please? Why steal my trust, I want it back. Why make me work for you and not pay me - treat me as your slave. Out of the three children in the house who has to earn the right to eat, sleep and dress? Why brutally tear me from my family at school and place me where you want to? I want that family back please.

Liesl's story is slightly different in that the narrative focus is on the strong mother, but she also refers to her own suffering as a child 'abandoned' by her father:

Perhaps he is fighting his own demons too, maybe that's why he has abandoned me. And now I am bleeding.

\footnotetext{
${ }^{3}$ Tik is the slang name given to the stimulant drug, Methamphetamine. This drug is a much more potent version of its parent drug, amphetamine. It is a widely used in the townships around Cape Town. Dagga is a Southern African slang term for marijuana.
} 
The consequences, for themselves, of emotionally and physically absent fathers in the digital stories students made at the beginning of the year were, as outlined above, underpinned by the idealised nuclear family headed by a male breadwinner. These consequences were presented as overwhelmingly negative, if not traumatic, vividly so, by all of the 40 students who produced digital stories focusing on their relationships with their fathers. In the next part of the discussion we consider the extent to which and ways in which these ideas developed over the course of the year. We do this through a consideration of the literature reviews each student conducted later in the year. In terms of this review students were invited to select a topic or theme that was important to them and that had emerged from either their digital story or their teaching practice experiences to conduct a brief desk top study and to offer recommendations of how their learnings may be employed in their future teaching profession.

\section{Continuities in the dominant narratives in the literature reviews}

The literature reviews selected for consideration here are the work of three students who conducted desk top studies exploring writing about missing fathers, by contrasting their own personal experiences, international and local literature and interviews with friends, family and teachers. In many ways the reviews these students produced reinscribed the dominant discourses of 'broken families' outlined earlier in this paper - exemplified by the title of Holborn and Eddy's 2011 paper, 'Healing the South African Family', discourses that are critiqued by a minority of authors (Clowes, Ratele and Shefer 2013; Lewis and Lamb 2004; Lupton and Barclay 1997). All three students drew on the literature to reinscribe the 'missing father' phenomenon as a problem, requiring a solution, and a problem primarily for the individual.

Sheree, for example in her essay, writes: '... absent fathers are simply father figures who are not present in their children's lives. This phenomenon leads to many different issues for the children affected.' At the same time, echoing dominant understandings of absent fathers, she draws attention to the personal impact an absent father has had on her life that she was never able to fulfil her potential: '... I was always told I had so much "potential”, which wasn't being reached. I did not see the ability I had, I was distracted by the anger I felt inside.'

Liesl foregrounds the negative impact of absent fathers in her review:

What these fathers fail to understand is that when they abandon their children, their actions forces the mothers to take on the burden of consuming both roles as mother and father and as a direct result has a negative impact on the child.

Talking about financial strains put on one-income families, for example, Sheree writes: 'In many cases, the children would be expected to fend for themselves, or leave school to help support their siblings', as the working parent has to '... focus on making ends meet, rather than dealing with emotional issues at home'. In a similar fashion citing a range of local and international literature, Liesl argues that the stress experienced by single mothers and the absence of a father, has a '... negative impact on the child's development and behaviour in the school environment', as well as a 'child's development in school'. Finally 
Magmoed cites statistics that show that in particular paternal orphans lead to 'worse schooling outcomes'.

All three students, in other words, draw on literature to reinforce the dominant narrative produced in the digital stories showing the negative impact on children's wellbeing of missing fathers. Using themselves as examples they foreground how such children experienced neglect, lower school performances or increased behavioural problems.

\section{Moving from blame to understanding}

At the same time, however, that they were reproducing the deficit discourse outlined above these three students were also starting to develop deeper understandings of broader social processes underpinning the absence of fathers from the archetypal nuclear family. All three students, for example, drew on statistical studies as well as historical and other texts to locate 'missing' South African fathers in the larger historical socio-economic context. Both Magmoed and Liesl for example drew on literature to show that '... apartheid played a big role in what's happened, the social injustice ...' (Liesl) or to note that the anti-apartheid struggle saw South African men killed, abducted, incarcerated, leaving homes without their fathers (Magmoed):

In the apartheid of South Africa men were the gender that fought the physical battles and they were killed many times or abducted and their families were never notified of their incarceration. Thus many homes were left without fathers and this is what shot the orphan statistics sky high in South Africa.

'South Africa', observed Sheree in a similar vein, 'has a long history of children not living consistently with their biological parents' and this was 'due to apartheid, so called "black" families were at a disadvantage for a long time, and in those difficult socio-economic times, these families were not able to break the cycle of absent parents.'

In drawing attention to the importance of context and history in making sense of what she labelled an 'epidemic', Liesl suggested that the absence of so many men from the homes and families of their children needed to be understood as a social rather than an individual problem:

From an outsider's viewpoint the magnitude of the absent father epidemic in South Africa may stem from the notion that fathers are running away from their responsibilities...however given the South African context and its past one cannot overlook the fact that the problem may not be as much about the act of a father running away from his responsibility.

Fathers, she went on to suggest, may absent themselves because of normative expectations around the providing father '... in our country a popular belief held, is if fathers are not financially supporting their children, that they should rather distance themselves from their children'.

In writing about the broader societal expectations of men, Sheree further drew attention to how 'the modernization and urbanization of our lives has placed pressures on men in 
the family to create a better livelihood.' Sheree suggested that peer pressure, societal pressures and norms, the access to infinite information, contributed to lower self-esteem', that pushed men to seek help in the form of 'female companionship, alcohol and drugs. This causes many families to break up...'

While, on the one hand, there is evidence that these students were beginning to consider some of the ways in which individual men's failure to live up to normative expectations of successful masculinity are rooted in social and historical processes, there was also evidence of essentialist understandings of gender that reinscribed the dominant discourses expressed in the digital stories. Magmoed, for example, both explained and justified the absent/ missing father from the normative nuclear family by drawing on discourses emerging out of evolutionary biology. 'Men' he wrote, have the 'animal instinct to move around and find multiple mating partners just like in nature and this results in the men moving from one partner to the other and leaving any children with the mothers', who are likewise 'programmed to be nurturers and protectors'.

Through their consideration of how the legacies of the past shape contemporary conditions, the students whose writing we discuss here began to arrive at different (and sometimes contradictory) understandings of absent fathers compared to those they expressed in their digital stories. On the one hand they drew attention to a range of explanations found in the literature for the widespread absence of South African men from their families (see Holborn and Eddy 2011 for a summary of these). While this challenges the notion of individual deadbeat fathers through locating the problem as political rather than personal, it also tends to reinforce the normativity of the nuclear family precisely because such solid and convincing explanations for missing fathers are available. Likewise, pointing to evidence that the supposedly normative nuclear family lying at the heart of the absent father discourse has not been common in South Africa 'for decades' (Bozalek 2007) implies that it once was - while simultaneously begging the question of precisely when (if indeed ever) it might have been normative. For these students, as we show in the next section, reflecting on their own experiences and contexts against this literature opened possibilities for rethinking the stereotypes around absent fathers in ways that offered more robust challenges to the dominant discourse of deficit.

\section{Discontinuities in dominant discourses and emerging understandings}

As exemplified in the three examples above, the literature reviews that focused on absent fathers saw the deficit narrative of the digital stories combined with research offering similar narratives to reproduce and strengthen the understanding of absent fathers as a major problem. Students found their personal narratives of deficit validated by the literature. At the same time, however, the literature presented students with the possibility that missing fathers could - perhaps should - be understood as the result of broader social and historical forces rather than the result of the choices made by individual men to abrogate responsibility for their children and families. As Liesl emphasised in the follow up interview, 'when the literature review came, I researched, I researched, I researched and I realized that okay cool, it is a problem but it's not only my problem.' And where students made overt connections between their own experiences and the literature, more insights offering possibilities for challenging dominant discourses, as we discuss next, emerged. 
Magmoed drew on his own experiences and observations to emphasise the inadequacies of the literature in both the literature review and in the follow up interview. 'It was interesting' he observed in his literature review 'to see the similarities in character [of my friends with missing fathers] they were always firm and tough and seemed to be more mature than their age group, why is this?' In asking why friends of his who had grown up without fathers seemed more mature, Magmoed began to challenge the discourse of deficit. In the interview he began to develop this idea by suggesting that there might be advantages to absent fathers that were not adequately explored in the literature:

The research says that they [children with absent fathers] are disadvantaged by about two years in schooling but for me I think they are advantaged because ... the drive and the success rate that I see in my friends; I feel that somebody that's a parental orphan actually has an advantage.

In making connections between the academic exercise of the literature review and her own experiences Liesl explained, in the interview, that the topic of absent fathers:

...was very special to us because we were personally affected by it. That's what made it ... it gave you oomph to want to do it ... So I just think it's like your own passion, it's like are you really passionate about this and with me, it's like, hey I'm going to research absent fathers but actually when I got into research I read up on myself. And then that's where I actually got this passion from.

Liesl went on to point out that she had been unable to find much research exploring the phenomenon of missing fathers in South Africa and that this was a problem:

There's no like research, there's no papers available for everyone to talk or no-one's talking about it. No-one's talking about it. It's like at one point, I had to like, go to like, I had to search for papers like American papers'.

Perhaps the most radical challenge of dominant narratives around fatherhood was presented by Sheree, who called for a 'shift of thinking', one that would challenge the 'unrealistic expectations' of South African families that position the nuclear family as normative:

... many of us have been indoctrinated with a preconceived notion of what a family should be like. A mother, a father, and 2.5 children, basically the perfect family... this creates an expectation, when this expectation is not met, it leads to disappointment.

Rather than seeing the missing father as the cause of children acting out or seeking attention in 'not very positive ways', Sheree, in her literature review, considered whether it might be the unmet expectations produced through unrealistic normative discourses that generate the anxiety and distress foregrounded in the digital stories:

It is not impossible to have a traditional nuclear family, but statistically, it is difficult to maintain. Once our communities are more educated on blended families, I feel that acceptance of circumstances will be easier. Acceptance in a sense of finding solace within 
mixed family backgrounds, and being 'okay' with that aspect...The fact remains that, children need guidance, support and love. It does not matter how it's given, as long as it is received.

In the interview, and echoing the work of Bozalek (2007) she underlines this position, by reflecting on her own lived experience in a blended family:

Family comes in all forms, blood or not. Family cannot be defined by a status quo. This is the South African norm. Most families consist of multiple parties and sometimes have many different parents and children from various parents. This is the way South African families are, at least in my community. And I feel it should not be deemed as a bad thing necessarily. Most families work even with the 'broken' pieces.

In drawing on her own experiences to point to the significance of what she labels 'blended families' in the South African context, Sheree reiterated the call by Brown and Barker (2004) to explore the roles of extended kin networks, of maternal and paternal uncles, grandfathers, stepfathers and other masculine role models . Sheree's suggestion is a call for recognition that the gendered behaviours and activities associated with 'fathering' are for most South African families a set of activities and behaviours that have been performed and shared by differently positioned men. It is precisely the discourse of the normative patriarchal nuclear family that Sheree highlights that is problematic.

\section{Conclusions}

As examples of dominant understandings around families, fathers and fatherhood, the digital stories foregrounding absent fathers that we explored in this paper were premised on the supposedly normative nuclear family, a family structure that has never in fact been normative in South Africa (Bozalek 2007). In the stories told by these students the devastating impact of their father's emotional or physical absence is - perhaps understandably - not situated against the complexities of the South African context. The result, as suggested by Gachago (2015) and Poletti (2011), is that these stories interact with dominant narratives in a dialectic that reinforces particular understandings, in what Clowes, Ratele and Shefer (2013) have called a discourse of deficit that does not accurately reflect the realities of South African families.

To disrupt these cycles of reinforcement is difficult, but not impossible, as we attempt to show in this paper. We foreground examples of the work of three students who drew on the collective narratives developed in the digital stories at the beginning of the year to understand that their experiences of an absent father were shared with a significant number of other students. We go on to show how these three students began to develop more critical insights by finding themselves and their stories both inside and outside the literature.

The emotional engagement with their own story, coupled with the sharing and listening to their peers stories, against literature that fails to reflect South African lived realities facilitated students' entering into a space of contestation, a 'theorizing from the flesh' (Benmayor 2008). The following quote by Liesl describes the entanglement of personal stories, collective narratives and literature. 
I was like so emotionally overwhelmed by everything. I went through the digital story. That helped me because then it helped me deal with it because I carried it around but I never actually looked at like stared it in the eye, face to face. That was the first process of dealing with it, the digital story. It helped me talk. I spoke about it, like I actually realized that okay, cool, I'm not the only one. I can speak to my peers about it as well and my peers, like my friendship in the group that I have, they showed such compassion to me that I was like, you know what, it's cool, I can get through this. I can get through this. The literature review came. I researched, I researched, I researched and I realized that okay cool, it is a problem but it's not only my problem.

We suggest that the learning in this course has gone beyond an understanding of digital storytelling as a social pedagogy (Benmayor 2008, 198) - an approach that relies heavily on student collaboration through sharing and disclosure of often painful memories. We argue, instead, that the learning in this course leans more towards Oppermann's (2008, 184) conclusion that "digital stories act as contact zones between the cognitive and the affective" and that, carefully scaffolded, there are ways to minimize the inherent risk of personal stories of uncritically reinforcing the dominant narratives (and the power inequalities that they express) in the classroom. In particular in teacher education, where students need to be prepared to engage and challenge dominant discourses, this is essential. Working with personal stories can only be productive if the socio-historical context is acknowledged and difficult knowledges are challenged and critiqued. This would allow students to both learn from and about the world, as Britzman (2000) suggests.

A question that remains revolves around the nature and extent of the scaffolding offered. Would a preselection of critical texts by the teacher have helped, as Benmayor (2008) or Matias and Grosland (2016) suggest? Or would it have taken away from the kind of ownership that students such as Sheree felt when independently discovering literature that helped them challenge dominant narratives on their own? How could we have facilitated students' literature reviews to enter a space of contestation? As we have shown above, this talking back to the literature is messy, uneven, complicated, inconclusive, and often contradictory. However, it also provides small openings for a more critical understanding of the lived experience and the literature urgently needed in contested spaces such as teacher education in South Africa. 


\section{References}

Alvanoudi, A. 2009. Teaching gender in the neoliberal university. In Teaching with the 3rd wave: New feminists explorations of teaching and institutional context. Teaching with Gender. European Women's Studies in International and Interdisciplinary Classrooms. eds. D Gronold, B Hipfl and L Pedersen. Utrecht: Athena and Centre for Gender Studies.

Apple, M. 2001. Gender meets neoliberalism. Discourse: Studies in the cultural politics of education 22(1): 115-118.

Arnfred, S., 2001. Simone de Beauvoir in Africa: 'woman 1/4 the second sex?' Issues of African feminist thought. In Svensk genusforskning i va"rlden. Globala perspektiv $i$ svensk genusforskning och svensk genusforskning i ett globalt perspektiv. ed. A Johansson. 62-83. Goteborgs Universitet: Nationella Sekretariatet fo " $\mathrm{r}$ genusforskning.

Aveling, N. 2001. 'Where do you come from?': Critical storytelling as a teaching strategy within the context of teacher education. Discourse: Studies in the Cultural Politics of Education 22(1): 35- 48.

Benick, G. 2008. Digital storytelling and diasporic identities in Higher Education. In Collected Essays on Learning and Teaching 5: 147-152.

Benmayor, R. 2008. Digital storytelling as a signature pedagogy for the new humanities. Arts and Humanities in Higher Education 7: 188-204. http://doi.org/10.1177/1474022208.

Bozalek, V. 2004. Recognition, resources, responsibilities, using students' stories of family to renew the South African social work curriculum. PhD diss., Utrecht University.

Bozalek, V. 2007. Analysing a text on the prevailing paradigm of 'family' in the 'psy' professions. In The gender of psychology, ed. T. Shefer, F. Boonzaier, and P. Kiguwa 151-164. Cape Town: UCT Press.

Brown, J. and Barker, G. 2004. Global diversity and trends in patterns of fatherhood. In Supporting fathers: Contributions from the international fatherhood summit 2003. 16-43. Den Haag: Bernard van Leer Foundation.

Burgess, B. and Russell, G. 2004. Fatherhood and public policy. In Supporting fathers: Contributions from the international fatherhood summit 2003. 108-145. Den Haag: Bernard van Leer Foundation.

Burman, E. and Parker, I. 1993. Discourse analytic research: Repertoires and readings of texts in action. London: Routledge.

Britzman, D. P. 2000. Teacher Education in the Confusion of Our Times. Journal of Teacher Education 51 (3): 200-205. doi:10.1177/0022487100051003007.

Choules, K. 2007. Social change education: Context matters. Adult Education Quarterly 57(20): 159- 176.

Clowes, L, Ratele, K and Shefer, T. 2013. Who needs a father? South African men reflect on being fathered. Journal of Gender Studies 22(3): 255-267.

Condy, J. 2015. The construction and transformation of pre-service teacher's individual, social and professional identities during a Digital Storytelling module. In Telling stories differently: Engaging 21st century students through digital storytelling, ed. J Condy.141-152. Cape Town: SunMedia.

Connell, R. 2014. Global tides: Market and gender dynamics on a world scale. Social Currents 1(1): 5-12. 
Coventry, M. 2008. Engaging gender: Student application of theory through digital storytelling. Arts and Humanities in Higher Education 7(2): 205-219.

Crehan, K. 1997. The fractured community - landscapes of power and gender in rural Zambia. Berkeley, CA: University of California Press.

Desai, Z., Giliomee, H., Jordan, P., Krog, A., Kulati, T., Lehoko, K., Leibowitz, B and James, W. 2004. Manifesto on Values, Education and Democracy. Education. Pretoria: National Department of Education. http://www.info.gov.za/view/DownloadFileAction?id=70295.

Gachago, D., Ivala, E., Condy, J., and Chigona, A. 2013. Journeys across difference: Preservice teacher education students' perceptions of a pedagogy of discomfort in a digital storytelling project in South Africa. Critical Studies in Teaching and Learning 1(1):22-52. http://doi.org/10.14426/cristal.vlil.4.

Gachago, D., Cronje, F., Ivala, E., Condy, J., and Chigona, A. 2014. Using digital counterstories as multimodal pedagogy among South African pre-service student educators to produce stories of resistance. Electronic Journal of E-Learning (eJeL) 12(1): 29-42.

Gachago, D. 2015. Sentimentality and digital storytelling: Towards a post-conflict pedagogy in preservice teacher education in South Africa. PhD diss., University of Cape

Town. https://open.uct.ac.za/bitstream/handle/11427/16537/thesis_hum_2015_gachag o_daniela.pdf?se quence $=1$.

Gachago, D., Ivala, E., Chigona, A., and Condy, J. 2015. Owning your emotions or sentimental navelgazing: Digital storytelling with South African pre-service student educators. Journal of Cultural Science 8(2): 18-35.

Gumble, A. 2012. Finding a voice: Freedom through digital literacies. The Educational Forum 76(4): 434-437.

Haug, F. 1992. Beyond female masochism: Memory work and politics. London \& New York: Verso.

Holborn, L. and Eddy, G. 2011. First steps to healing the South African family. Johannesburg: South African Institute of Race Relations.

hooks, b. 2000. Feminist theory: From margin to center. London: Pluto Press.

Jamissen, G. 2010. Poetic reflection through digital storytelling - a methodology to foster professional health worker identity in students. Seminar-net International Journal of Media, Technology and Lifelong Learning 6(2).

Jean, E., and John, A. 2008. The uses of MultiMedia: Three digital literacy case studies. Media International Australia Incorporating Culture and Policy 59-72.

Kobayashi, M. 2012. A digital storytelling project in a multicultural education class for pre- service teachers. Journal of Education for Teaching 38(2): 215-219.

Lambert, J. 2010. Digital storytelling cookbook. Berkeley, CA: Center for Digital Storytelling.

Langa, M. 2010. Adolescent boys talk about absent fathers. Journal of Psychology in Africa 20 (4): 527-536.

Lamb, M.E., and Lewis, C. 2004. The development and significance of father-child relationships in two-parent families. In The role of the father in child development, ed. M E Lamb, (4th edition). New York, NY: John Wiley \& Sons. 
Long, B. 2011. Digital storytelling and meaning making: Critical reflection, creativity and technology in pre-service teacher education. In Proceedings of the Digital storytelling conference 1-27.

Lupton, D. and Barclay, L. 1997. Constructing fatherhood: Discourses and experiences. London: Sage.

Madhavan, S., Richter, L., Norris, S. and Hosegood, V. 2014. Father's financial support of children in a low income community in South Africa. Journal of Family Economic Issues 35: 452-463.

Maher, F. and Thompson-Tetreault, M.K. 2001. The feminist classroom: Dynamics of gender, race, and privilege. New York: Basic Books.

Matias, C.E., and Grosland, T.J. 2016. Digital storytelling as racial justice: Digital hopes for deconstructing whiteness in teacher education. Journal of Teacher Education 67(2): 152-164. http://doi.org/10.1177/o022487115624493.

Marsiglio, W. 1993. Contemporary scholarship on fatherhood culture, identity and conduct. Journal of Family Issues (December) 14(4): 484-509.

McKillop, C.R. 2004. 'Stories About ... Assessment': Supporting reflection in art and design higher education through on-line storytelling. In International Narrative and Interactive Learning Environments Conference (NILE 2004).

National Department of Education. 2001. Education White Paper 6: Special Needs Education, Building an Inclusive Education and Training System. Pretoria: Government Printers. http://www.info.gov.za/whitepapers/2001/educ6.pdf.

Nash, M. 2013. Reflections on teaching gender to Australian sociology undergraduates in the neoliberal postfeminist classroom. Journal of Sociology 49(4): 411-424.

Oppermann, M. 2008. Digital storytelling and American Studies: critical trajectories from the emotional to the epistemological. Arts and Humanities in Higher Education 7(2): 171-187. http://doi.org/10.1177/1474022208.

Parker, I. 1992. Discourse dynamics: Critical analysis for social and individual psychology. London: Routledge.

Potter, J. and Wetherell, M. 1987. Discourse and social psychology: Beyond attitudes and behaviour. London: Sage.

Poletti, A. 2011. Coaxing an intimate public: Life narrative in digital storytelling. Continuum 25(1): 73-83.

Ratele, K., Shefer, T., and Clowes, L. 2012. Talking fathers: A critical examination of men's constructions and experiences of fatherhood and fatherlessness. South African Journal of Psychology 42(4): 553-563.

Reed, A., and Hill, A. 2012. 'Don't keep it to yourself!': Digital storytelling with South African Youth. International Journal for Media, Technology and Lifelong Learning, 8(2). http://seminar.net/index.php/component/content/article/75current-issue/146- dont-keep-it-toyourself-digital-storytelling-with-south-africanyouth.

Richter, L. and Morrell, R., eds. 2006. Baba: Men and fatherhood in South Africa. Cape Town: HSRC Press.

Robin, B.R. 2008. Digital storytelling: A powerful technology tool for the 21st century classroom. Theory into Practice 47(3): 220-228. http://doi.org/10.1080/00405840802153916. 
Sadik, A. 2008. Digital storytelling: a meaningful technology-integrated approach for engaged student learning. Education Technology Research Development 56: 487506.

Sleeter, C. and Tettegan, S. 2002. Technology as a tool in multicultural teaching. Multicultural Education (Winter) 10(2): 3-9.

Stewart, K. and Gachago, D. (2016). Being human today: A digital storytelling pedagogy for transcontinental border crossing. British Journal for Educational Technology 47(3): 528-542.

Swartz, S. and Bhana, A. 2009. Teenage Tata: Voices of young fathers in South Africa. Cape Town: HSRC Press.

Thumbran, J.K. 2010. Digital storytelling and the facilitation of social justice in contexts of social injustice. Master Diss., Tilburg University.

Van Dijk, T.A. 1993. Principles of critical discourse analysis. Discourse and Society 4 (2): 249-283.

Walters, L.M., Green, M.R., Wang, L., and Walters, T. 2011. From heads to hearts: Digital stories as reflection artifacts of teachers' international experience. Issues in Teacher Education 20(2): 37-52.

Weber, B. 2010. Teaching popular culture through gender studies: feminist pedagogy in a postfeminist and neoliberal academy? Feminist Teacher 2(2): 124-138.

Weis, T.M., Benmayor, R., O’Leary, C., and Eynon, B. 2002. Digital technologies and pedagogies. Social Justice 29(4): 153-167.

Zembylas, M., 2013. The "Crisis of Pity" and the radicalization of solidarity: Toward critical pedagogies of compassion. Educational Studies, 49(6): 504-521. http://www.tandfonline.com/doi/abs/10.1080/o0131946.2013.844148 